\title{
Actin- and clathrin-dependent mechanisms regulate interferon gamma release after stimulation of human immune cells with respiratory syncytial virus
}

\author{
Jop Jans, Hicham elMoussaoui, Ronald de Groot, Marien I. de Jonge and Gerben Ferwerda*
}

\begin{abstract}
Background: Respiratory syncytial virus (RSV) can cause recurrent and severe respiratory tract infections. Cytoskeletal proteins are often involved during viral infections, either for cell entry or the initiation of the immune response. The importance of actin and clathrin dynamics for cell entry and the initiation of the cellular immune response against RSV in human immune cells is not known yet. The aim of this study was to investigate the role of actin and clathrin on cell entry of RSV and the subsequent effect on T cell activation and interferon gamma release in human immune cells.

Methods: Peripheral blood mononuclear cells and purified monocytes were isolated from healthy adults and stimulated in vitro with RSV. Actin and clathrin dynamics were inhibited with respectively cytochalasin D and chlorpromazine. T cell receptor signaling was inhibited with cyclosporin A. Flow cytometry was used to determine the role of actin and clathrin on cell entry and T cell activation by RSV. Enzyme-linked immunosorbent assays were used to investigate the contribution of actin and clathrin on the release of interferon gamma.

Results: Cell entry, virus gene transcription and interferon gamma release are actin-dependent. Post-endocytic processes like the increased expression of major histocompatibility complex II on monocytes, T cell activation and the release of interferon gamma are clathrin-dependent. Finally, $T$ cell receptor signaling affects $T$ cell activation, whereas soluble interleukin 18 is dispensable.

Conclusion: Analysis of cell entry and interferon gamma release after infection with RSV reveals the importance of actin- and clathrin-dependent signaling in human immune cells. Insights into the cellular biology of the human immune response against respiratory syncytial virus will provide a better understanding of disease pathogenesis and may prove useful in the development of preventive strategies.
\end{abstract}

Keywords: Respiratory syncytial virus, Cell entry, Innate immunity, Molecular biology, Monocytes, Interferon gamma, T cells

\section{Background}

Respiratory syncytial virus (RSV) is a negative-sense single stranded RNA virus of the family Paramyxoviridae and is a major burden on the current health care system. In healthy adults, RSV infections are limited to the upper respiratory tract, but remarkably do not generate long-term immunity [1]. In children and elderly, RSV can cause severe lower respiratory tract infections

\footnotetext{
* Correspondence: gerben.ferwerda@radboudumc.nl

Laboratory of Pediatric Infectious Diseases, Department of Pediatrics,

Radboud Institute for Molecular Life Science, Radboud university medical center, P.O. Box 91016500 HB Nijmegen, The Netherlands
}

requiring admission to an intensive care unit in a small percentage of cases.

The first line of defense against RSV infection consists of epithelial cells. Upon infection, epithelial cells attract antigen-presenting cells, including dendritic cells and monocytes. Monocytes and macrophages are able to engulf pathogens leading to antigen-presentation. The monocytic cell is one of the major immune cell types that is susceptible to RSV infection and the role of monocytes and macrophages in the pathogenesis of RSV infections has been appreciated for decades [2-7]. During RSV infection in mice, the recruitment of monocytes 
from the bloodstream limits viral replication and reduces disease severity [8]. Viral particles can interact with receptors at the membrane of monocytes resulting in attachment, uptake and initiation of the immune response [9-11]. Under many circumstances, actin or clathrin are essential for receptor-mediated internalization [12-16]. Internalization can be regulated differentially dependent on the cell type. Uptake of transferrin occurs clathrindependent in macrophages and is not dependent on clathrin in epithelial cells [17]. Cell-specific differences in entry mechanisms between epithelial cells and fibroblasts have been shown for human cytomegalovirus [18]. Previous studies have studied the internalization of RSV in epithelial cells [19-22]. No data is available regarding cell entry of RSV in monocytes, which raises the question whether internalization of RSV occurs differentially in innate immune cells. After internalization, immune cells are involved in antigen-presentation, $T$ cell activation and the production of cytokines like interferon gamma (IFN- $\gamma$ ). IFN- $\gamma$, a type II interferon, plays a critical role in the immune response against viral infections [23]. T cell activation may occur through cytokines like interleukin 18 (IL-18) or through stimulation of the T cell receptor (TCR). The relationship between cell entry, $\mathrm{T}$ cell activation and subsequent release of IFN- $\gamma$ during RSV infection in primary human cells is unknown. Peripheral blood mononuclear cells (PBMCs) provide a useful model to investigate the impact of cellular pathways on antiviral immunity. PBMCs contain important cells that reflect the immune response against RSV like dendritic cells, monocytes and $\mathrm{T}$ cells [4, 24-27]. In this study, we aimed to investigate the regulation of IFN- $\gamma$ by actin- and clathrin-dependent mechanisms after stimulation of human immune cells with RSV. For this, we used pharmacological inhibitors to inhibit actin and clathrin. Hereby, the contribution of actin- and clathrindependent processes on cell entry, $\mathrm{T}$ cell activation and induction of IFN- $\gamma$ in primary human immune cells during RSV infection was studied.

\section{Results}

Cell entry and subsequent virus gene transcription of RSV in monocytes are actin-dependent

We first examined the dynamics of cell entry of RSV into $\mathrm{CD} 14^{+}$monocytes by using pharmacological inhibitors. Cytochalasin D (CytoD) and Wiskostatin (Wisko) have been used in previous literature to inhibit actindependent entry and chlorpromazine (CPZ) for clathrindependent entry [28-30]. A representative figure of the gating strategy to determine internalization of RSV into monocytes is shown (Fig. 1a). Disruption of actin filaments in monocytes with CytoD or Wisko significantly reduces the internalization of RSV whereas inhibition of clathrin with $\mathrm{CPZ}$ has no effect on the internalization indicating that cell entry is an actin-dependent process (Fig. 1b). Extracellular binding of RSV on membrane of monocytes occurred and is not reduced by pre-treatment of monocytes with CytoD or CPZ (Fig. 1c). To confirm the inhibitory effect of CytoD on cell entry, PBMCs were stimulated with RSV for $24 \mathrm{~h}$ and virus gene transcription was measured in monocytes. Treatment of PBMCs with CytoD abrogates virus gene transcription in monocytes whereas CPZ has no effect (Fig. 1d). Mean percentages of internalization, binding and virus gene transcription in untreated monocytes were respectively $29 \%, 13 \%$ and $4 \%$.

\section{IFN- $\gamma$ release after RSV infection is actin- and clathrin- dependent}

Previous literature shows that $\mathrm{T}$ cells are the main producers of IFN- $\gamma$ in our model of PBMCs and stimulation with RSV [24]. To determine whether the adaptive immune response against RSV is actin-dependent, the IFN- $\gamma$ release was measured after stimulation of PBMCs with RSV. Inhibition of actin with CytoD abrogates the RSVinduced IFN- $\gamma$ release (Fig. 2a). Although CPZ has no effect on the internalization of RSV, inhibition of clathrin reduces the release of IFN- $\gamma$ (Fig. 2b). Both CytoD and CPZ have no effect on $\mathrm{T}$ cell activation after stimulation with the non-specific $\mathrm{T}$ cell activator phytohaemagglutinin (PHA) (Fig. 2a-b). From this, we conclude that both cell entry and post-endocytic processes play a role in the adaptive immune response against RSV whereas mere binding of RSV to the cell membrane of monocytes is not sufficient to induce IFN- $\gamma$ release.

\section{T cell activation and upregulation of MHC-II after RSV infection are clathrin-dependent}

To address the discrepancy between clathrin-independent internalization and clathrin-dependent IFN- $\gamma$ release, we examined whether post-endocytic processes like T cell activation and upregulation of antigen-presenting molecules are clathrin-dependent. CD69 was used as an activation marker on T cells [31]. PHA was used as positive control for $\mathrm{T}$ cell activation. RSV induces activation of CD4 and CD8 T cells and pre-treatment of PBMCs with CPZ prevents $\mathrm{T}$ cell activation after RSV infection (Fig. 3a-b). To investigate whether the upregulation of antigen-presenting molecules is inhibited by $\mathrm{CPZ}$, the expression levels of MHC-I and MHC-II on monocytes was determined. RSV induces a significant increase of MHC-I and MHC-II expression on monocytes (Fig. 3c-d). Upregulation of MHC-I expression is not affected by treatment of PBMCs with CPZ (Fig. 3c). The RSV-induced upregulation of MHC-II expression is not present after pre-treatment of PBMCs with $\mathrm{CPZ}$ indicating that upregulation of MHC-II is clathrin-dependent (Fig. 3d). 


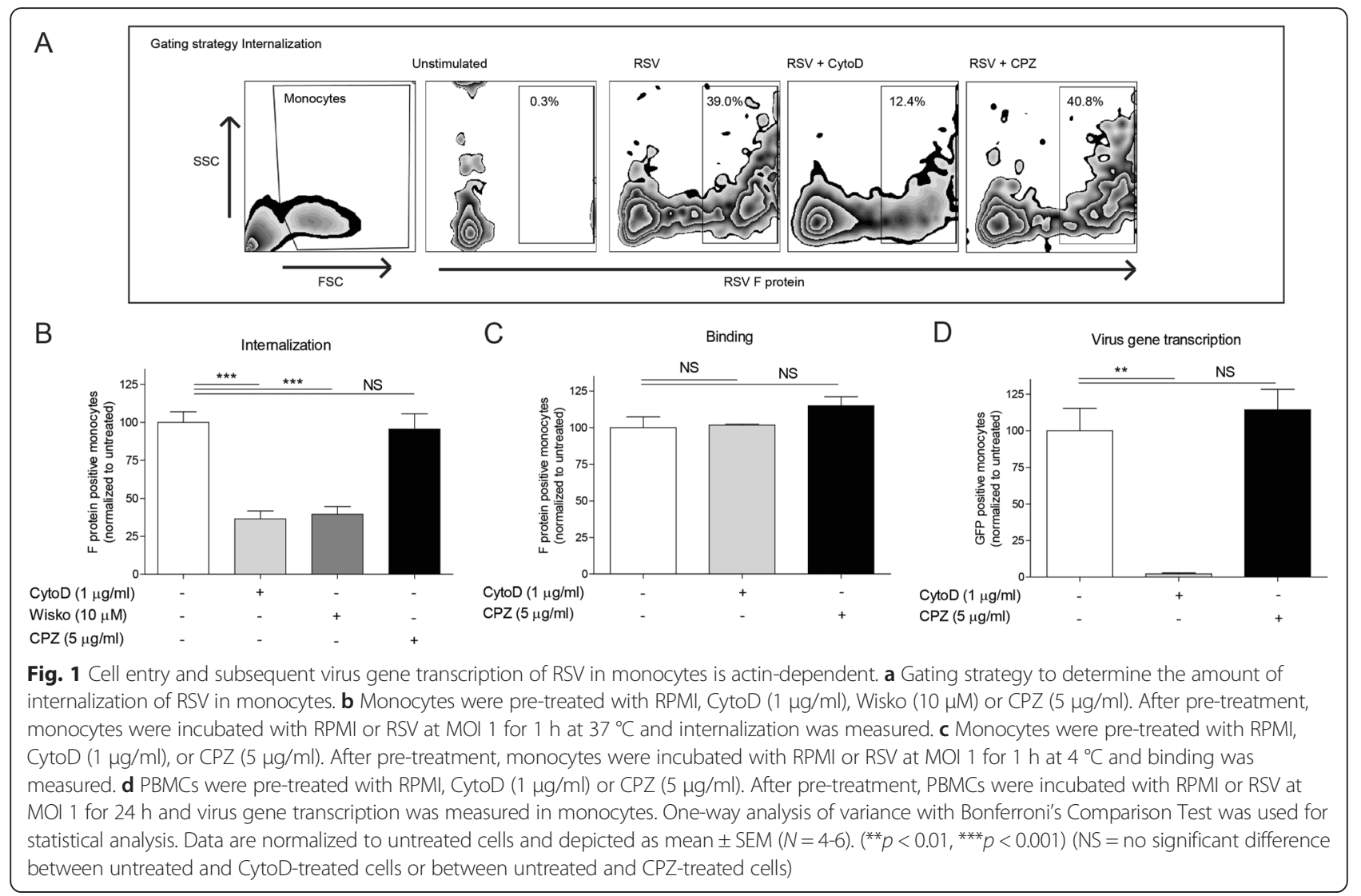

\section{IFN- $\gamma$ release after RSV infection is dependent on T-cell receptor signaling}

To confirm the role of antigen-presenting molecules and thereby TCR signaling as its ligand, we evaluated whether IL-18, as a soluble T cell activator, or TCR signaling affects the IFN- $\gamma$ release after RSV infection. Neutralization of IL-18 with IL-18 bp does not inhibit RSV-induced IFN- $\gamma$ release. As a control, we show that IL-18 bp is able to significantly inhibit Candida-induced
IFN- $\gamma$ response, which is consistent with previous literature (Fig. 4a) [32]. The release of IFN- $\gamma$ is inhibited when TCR signaling is blocked with cyclosporin A (CsA) (Fig. 4b).

\section{Discussion}

Internalization and subsequent virus gene transcription of RSV in human monocytes and the induction of IFN- $\gamma$ are actin-dependent. Although clathrin is not involved in
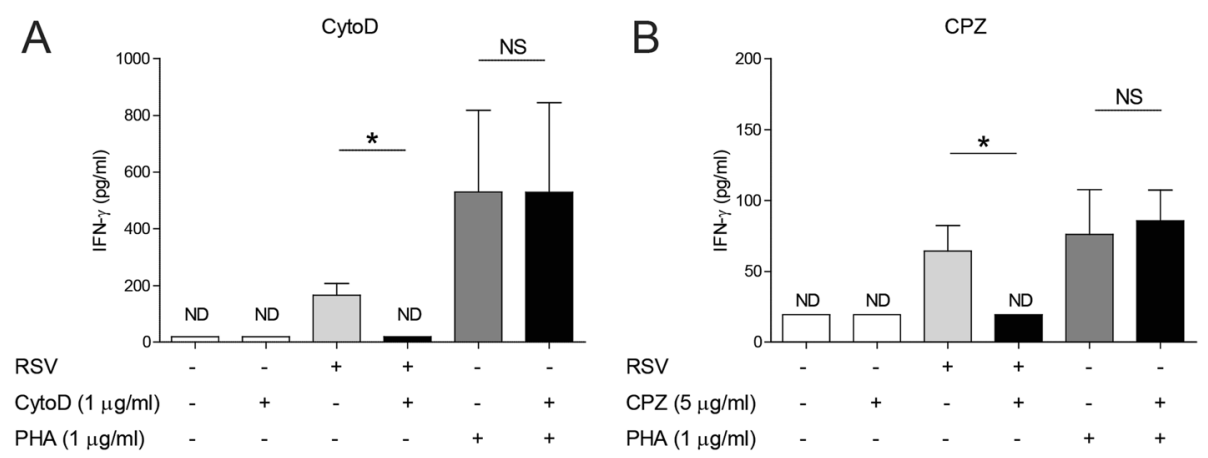

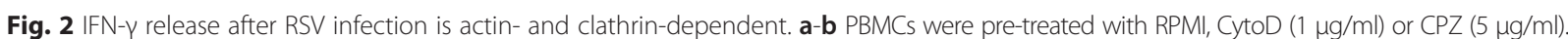
After pre-treatment, PBMCs were incubated with RPMI, RSV at MOI 1 or PHA $(1 \mu \mathrm{g} / \mathrm{ml})$ for $24 \mathrm{~h}$ and IFN- $\gamma$ release was measured. Lower limit of detection: $20 \mathrm{pg} / \mathrm{ml}$. Wilcoxon-signed rank test was used for statistical analysis. Data are mean \pm SEM $(N=4-6) .\left({ }^{*} p<0.05\right)(N D=$ non-detectable, NS $=$ no significant difference between untreated and CytoD-treated cells or between untreated and CPZ-treated cells) 


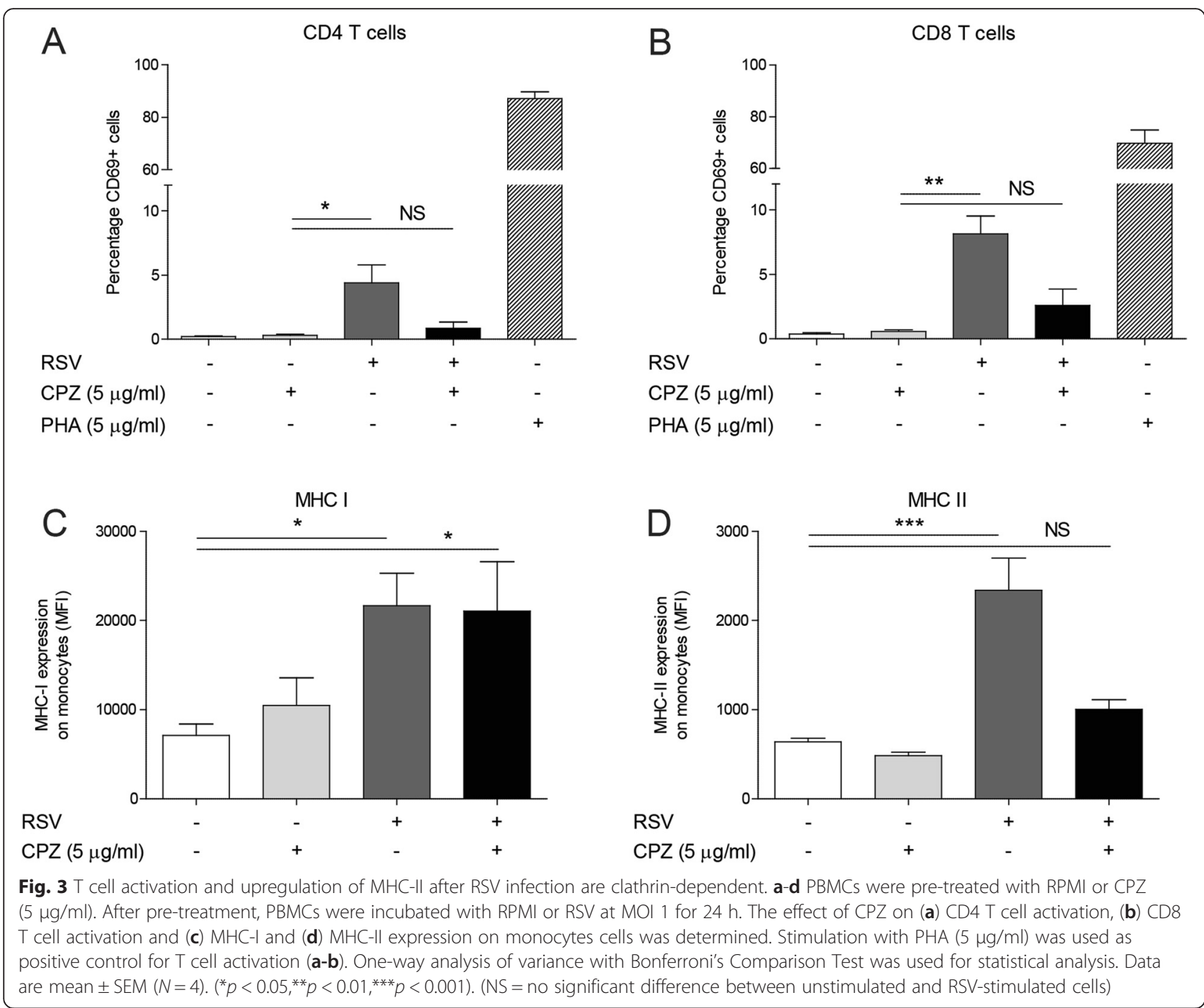

the internalization of RSV, upregulation of MHC-II on monocytes, $\mathrm{T}$ cell activation and the release of IFN- $\gamma$ after RSV infection are clathrin-dependent processes. Finally, $T$ cell receptor activation contributes to the RSV-induced IFN- $\gamma$ response whereas the production of IL-18 is dispensable.

Actin is required for cell entry of RSV in epithelial cells [19]. We have shown for the first time, that primary human monocytes also require actin to internalize RSV for subsequent virus gene transcription to occur. Actin plays an essential role in processes involving internalization, including receptor-mediated phagocytosis. For the Nipah virus, a paramyxovirus like RSV, infection induces the co-internalization of Nipah virus receptor ephrinB2 and, in general, many receptors are internalized in an actin-dependent manner [33-35]. Several receptors are involved in the recognition of RSV at the membrane, like Toll-like receptor 4 (TLR4), CD14 and nucleolin $[9,36]$.
Internalization of TLR4 and CD14 has been investigated upon bacterial ligand stimulation. In this process, internalization of TLR4 is dynamin-dependent and CD14 is actin-dependent [37, 38]. Clustering of nucleolin is dependent on actin [39]. Whether actin-dependent clustering of nucleolin occurs after RSV infection and whether it is necessary for internalization is unknown. Our finding that intact actin filaments are required for internalization of RSV in monocytes narrows the scope of potential receptors that co-occur with cell entry and are required for internalization. Besides cell entry, intact actin is required for virus filament formation, viral transmission and the production of cell-associated infectious virus by epithelial cells [40-43]. We observed an inhibitory effect of CytoD on the release of IFN- $\gamma$ during an incubation period of $24 \mathrm{~h}$. Inhibition of post-endocytic processes like virus filament formation and transmission could therefore explain the observed reduction of IFN- $\gamma$ 


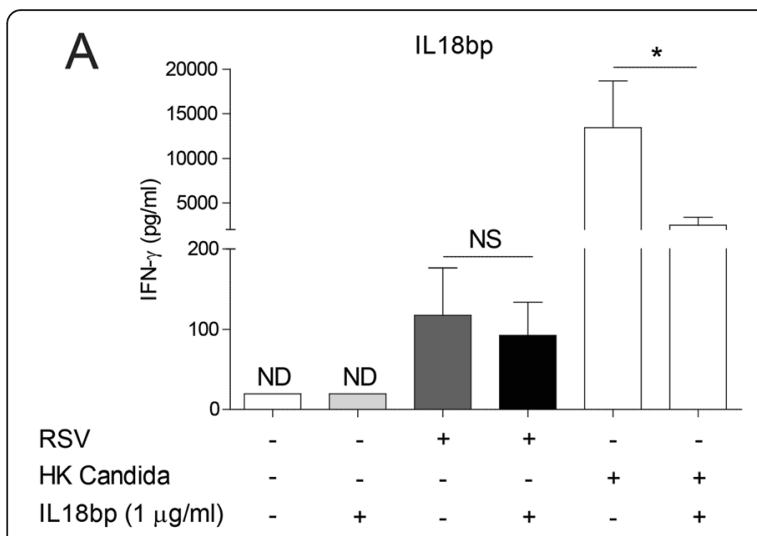

B

CsA

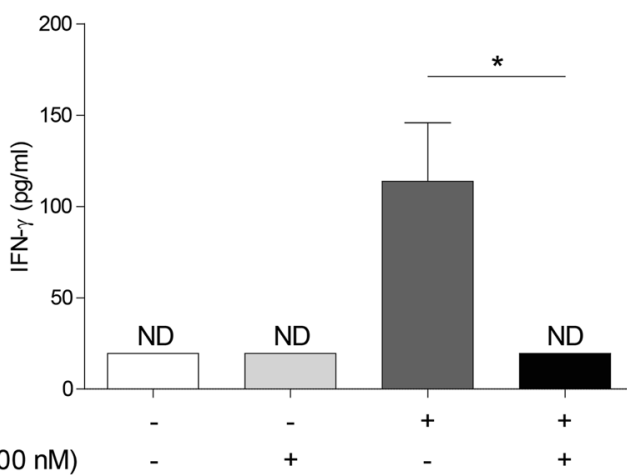

Fig. 4 IFN- $\gamma$ release after RSV infection is dependent on T-cell receptor signaling. a IL-18 bp was added to PBMCs simultaneously with RPMI, RSV at MOI 1 or heat killed Candida. IFN- $\gamma$ release was measured after $24 \mathrm{~h}$. b PBMCs were pre-treated with RPMl or CsA (100 nM). After pretreatment, PBMCs were incubated with RPMI or RSV at MOI 1 for $24 \mathrm{~h}$ and IFN- $\gamma$ release was measured. Lower limit of detection: $20 \mathrm{pg} / \mathrm{ml}$. Wilcoxon-signed rank test was used for statistical analysis. Data are mean \pm SEM $\left.(N=4-5) .{ }^{*} p<0.05\right)(N D=$ non-detectable) (NS = no significant difference between untreated and CPZ-treated cells)

after treatment with CytoD. However, in our model of PBMCs, monocytes exhibit abortive infection as no replicating virus is detected in the supernatant of PBMCs stimulated with RSV (data not shown). This is in line with the abortive infection of RSV in alveolar macrophages [44]. Therefore, the role of actin on virus filament formation and viral transmission may be applicable to epithelial cells but most likely would not play a role in our model.

After inhibition of actin with CytoD or Wisko, approximately $30 \%$ of the monocytes still remain positive for RSV F protein. Permeabilization of the cells in our assay will not exclude extracellular staining of RSV F protein and therefore the remaining RSV-positive monocytes after treatment could reflect extracellular binding of RSV. Because CytoD does not influence the extracellular binding of RSV, we conclude that actin dynamics are involved in the internalization of RSV by monocytes.
Actin-independent processes could also explain the incomplete prevention of internalization by CytoD. Fusion of the F protein of RSV with the cell membrane could result in entry of viral proteins and might act independently of actin filaments. Clathrin has previously been implicated for internalization of RSV in an epithelial cell line after an incubation period of $20 \mathrm{~h} \mathrm{[20].} \mathrm{Contrary,}$ others have shown that internalization of RSV after $1 \mathrm{~h}$ is not clathrin-dependent [19]. The authors conclude that discrepancies between these studies may arise due to a difference in experimental design. The incubation period of $1 \mathrm{~h}$ in our study excludes inhibition of postendocytic processes like viral replication and cell-to-cell transmission. In addition, differences between epithelial cells and monocytic cells have been described previously for internalization of nanoparticles and may explain our results compared to epithelial cells [17]. The role of cellular mechanisms on $\mathrm{T}$ cell activation can be studied in our model of PBMCs. Besides internalization, inhibition of actin dynamics reduces the IFN $-\gamma$ response. These data suggest that, at least in part, the intracellular compartment is involved in the induction of an adaptive response and binding of RSV to the outer membrane is not sufficient to induce IFN- $\gamma$ release. These results are in line with previous data indicating that intact RSV particles are not able to signal via membrane-associated receptors such as TLR4 [45].

In our study, inhibition of clathrin has no effect on the internalization of RSV by monocytes, but effectively reduces the induction of IFN- $\gamma$. CPZ at $5 \mu \mathrm{g} / \mathrm{ml}$ was the highest tolerable concentration without inducing cytoxicity (data not shown). Our data suggest that activation of $\mathrm{T}$ cells by RSV is clathrin-dependent. Calabia-Linares et al. observed the importance of clathrin in the formation of the immunological synapse between $\mathrm{T}$ cell and antigen-presenting cells [46]. Possibly, inhibition of clathrin reduces the IFN- $\gamma$ release due to improper formation of the immunological synapse and thereby inefficient $\mathrm{T}$ cell activation. Less than $1 \%$ of the $\mathrm{T}$ cells in the peripheral blood are RSV-specific T cells $[47,48]$. Therefore, the relative high percentage of $5-10 \% \mathrm{CD}^{+} 9^{+} \mathrm{T}$ cells after stimulation with RSV in our experiments most likely indicates that a general activation of $\mathrm{T}$ cells occurs. We demonstrate that clathrin plays an essential role in the upregulation of RSV-induced MHC-II expression on monocytes . The requirement of clathrin for MHC-II trafficking has been observed previously [49]. The role of MHC-II in the induction of IFN- $\gamma$ is strengthened by the observation that inhibition of TCR signaling, as a ligand for MHC-II, reduces the IFN- $\gamma$ response, whereas inhibition of IL-18 has no effect. The combination of reduced $\mathrm{T}$ cell activation and MHC-II expression suggests that clathrin plays a role in the interplay between innate and adaptive immunity against RSV. 
The simplification of in vivo RSV infections using our model of PBMCs could be a limitation of the study. Although others have shown that monocytes can be become infected with RSV and serve as an in vitro model, alveolar macrophages or inflammatory macrophages are the most likely target of infection in vivo [4]. Therefore, there could be differences in the immune response in vivo compared to our model. Pre-treatment of isolated monocytes with the inhibitors and performing a subsequent co-culture with autologous $\mathrm{T}$ cells could be considered as an alternative instead of simultaneous culture of all cells present in PBMCs. However, during RSV infection in vivo, multiple immune cells, including monocytes, natural killer cells and $\mathrm{T}$ cells are recruited to the lung tissue [8]. Our model can give more insights in the interplay between RSV and different immune cells that are present during RSV infection.

In conclusion, this study underlines the importance of actin and clathrin dynamics during RSV infections for cell entry and $\mathrm{T}$ cell activation. Currently, there is no effective treatment or vaccine against RSV infections. Understanding the different aspects of RSV disease pathogenesis and immunity, from early virus-cell interactions to final induction of the adaptive immune response may contribute to the development of novel therapies and effective vaccines.

\section{Conclusions}

The aim of this study was to investigate the role of actin and clathrin on cell entry of RSV and the subsequent effect on $\mathrm{T}$ cell activation and release of IFN- $\gamma$ in human immune cells. Cell entry in human monocytes, virus gene transcription and IFN- $\gamma$ release are actindependent. Post-endocytic processes like the increased expression of MHC-II on monocytes , T cell activation and the release of IFN- $\gamma$ are clathrin-dependent. Finally, $\mathrm{T}$ cell receptor signaling affects the release of IFN- $\gamma$, whereas soluble interleukin 18 is dispensable. Insights into the cellular biology of the human immune response against RSV will provide a better understanding of disease pathogenesis.

\section{Methods}

\section{Pharmacological inhibitors}

Actin-dependent pathways were inhibited by pre-treatment of cells with CytoD $(1 \mu \mathrm{g} / \mathrm{ml})$ or Wisko $(10 \mu \mathrm{M})$ and clathrin-dependent pathways were inhibited by CPZ $(5 \mu \mathrm{g} /$ ml) (Sigma-Aldrich). CsA (Sigma-Aldrich) and IL-18 bp (R\&D Systems, United Kingdom) were used to respectively inhibit $\mathrm{T}$ cell receptor signaling and IL-18. No cytotoxic effect determined as Annexin V+/7-AAD+ cells was observed when using the indicated concentrations of the inhibitor (data not shown).

\section{Cell isolation}

After obtaining informed consent, peripheral blood mononuclear cells (PBMCs) from healthy adults were isolated using Lymphoprep and isolation of monocytes from the PBMC fraction was performed using an indirect negative selection magnetic labeling kit (Monocyte Isolation Kit II human; Miltenyi Biotec). Each 96-well plate was filled with $5 \times 10^{5}$ PBMC per well or $1 \times 10^{5}$ isolated monocytes per well. The study was approved by the committee on Research involved Human Subjects of the Radboudumc.

\section{Culture of RSV}

RSV A2 containing an additional transcription unit encoding GFP (rgRSV) was cultured as previously described [50]. rgRSV was cultured on HeLa cells (ATCC, CCL-2) in Dulbecco's minimum essential medium (DMEM) with $10 \%$ fetal calf serum (FCS) and $1 \%$ penicillin/streptomycin. Near-confluent HeLa cells were infected with rgRSV and incubated for three days at $37{ }^{\circ} \mathrm{C}$. Cells were scraped and the suspension was centrifuged to remove cellular debris. rgRSV was ultracentrifuged on a sucrose cushion for purification and titrated on HeLa cells. Confluent HeLa cells (80-90 \%) were infected with fivefold viral dilutions for 20-22 h. Virus titer was determined by counting wells with $\geq 10$ and $\leq 100$ infected cells/view (CKX41 microscope; Olympus, Tokyo, Japan). rgRSV was snapfrozen and stored at $-80{ }^{\circ} \mathrm{C}$ until use.

\section{Internalization and binding assay}

PBMCs or isolated monocytes were treated with CytoD $(1 \mu \mathrm{g} / \mathrm{ml})$, Wisko $(10 \mu \mathrm{M})$ or CPZ $(5 \mu \mathrm{g} / \mathrm{ml})$ for $30 \mathrm{~min}$ at $37{ }^{\circ} \mathrm{C}$. For quantification of cell entry, monocytes were permeabilized with CytoFix/Perm (BD Biosciences) after incubation with RSV at MOI 1 ( $5 \times 10^{5} \mathrm{IU} /$ well) for $1 \mathrm{~h}$ at $37^{\circ} \mathrm{C}$. Cells were incubated for $30 \mathrm{~min}$ on ice with mouse anti-respiratory syncytial virus fusion protein antibody (Ab24011; Abcam). Goat anti-mouse IgG PE (BD Pharmingen) was used as secondary antibody. For the quantification of RSV binding, coincubations of PBMCs with RSV were performed for $1 \mathrm{~h}$ at $4{ }^{\circ} \mathrm{C}$ and cells were fixed with $1 \%$ paraformaldehyde before staining.

\section{T cell activation and MHC expression}

PBMCs were treated with CPZ $(5 \mu \mathrm{g} / \mathrm{ml})$ for $30 \mathrm{~min}$ at $37{ }^{\circ} \mathrm{C}$. PBMCs were stimulated with RSV at MOI 1 or with PHA $(5 \mu \mathrm{g} / \mathrm{ml})$ for $24 \mathrm{~h}$. CD69 expression, as $\mathrm{T}$ cell activation marker, was measured with flow cytometry. For gating, CD3 and CD4 or CD8 positive $\mathrm{T}$ 
cells were selected and the percentage of CD69 positive cells was determined. After pre-treatment with CPZ $(5 \mu \mathrm{g} / \mathrm{ml})$, PBMCs were incubated with RSV at MOI 1 for $24 \mathrm{~h}$ and the expression of MHC-I and MHC-II on monocytes was determined. For gating, CD14 positive cells were selected and the geometric mean fluorescence intensity (MFI) of MHC-I and MHC-II was determined.

\section{Flow cytometry}

Cell surface markers were stained with CD14 V500, CD14 AF647, CD3 V500, CD8 APC-H7, CD8 PE, CD4 PerCP-Cy5.5, CD69 Pe-Cy7, HLA-ABC PE and HLA-DR PE (BD Pharmingen). For quantification of RSV, mouse anti-RSV F protein (Ab24011; Abcam) and goat anti-mouse IgG PE (BD Pharmingen) were used. Virus gene transcription in monocytes was determined by gating CD14 positive cells as monocytes and calculating the percentage of GFP positive cells. Cytoxocity was determined by calculating Annexin V+/7-AAD+ cells (PE Annexin V Apoptosis Detection Kit I, BD Pharmingen). Events were acquired on an LSR II flow cytometer and analyzed using FlowJo.

\section{In vitro cytokine production}

PBMCs were treated with CytoD $(1 \mu \mathrm{g} / \mathrm{ml}), \mathrm{CPZ}(5 \mu \mathrm{g}$ / $\mathrm{ml}$ ) or $\mathrm{CsA}(100 \mathrm{nM})$ for $30 \mathrm{~min}$ at $37{ }^{\circ} \mathrm{C}$. After pretreatment, cells were stimulated with RSV at MOI 1, PHA $(1 \mu \mathrm{g} / \mathrm{ml})$ or heat-killed Candida albicans $\left(1 \times 10^{6} \%\right.$ well) for $24 \mathrm{~h}$. IL-18 bp $(1 \mu \mathrm{g} / \mathrm{ml})$ was added simultaneously with RSV. Concentration of interferon gamma were measured in the cell supernatants by enzymelinked immunosorbent assays (ELISA) (Sanquin Blood Supply, the Netherlands) with a lower limit of detection of $20 \mathrm{pg} / \mathrm{ml}$.

\section{Abbreviations \\ CPZ: chlorpromazin; CsA: cyclosporin A; CytoD: cytochalasin D; ELISA: enzyme-linked immunosorbent assay; IFN- $\gamma$ : interferon gamma; IL- 18: interleukin 18; IL-18 bp: interleukin 18 binding protein; MFI: geometric mean fluorescence intensity; MHC: major histocompatibility complex; MOl: multiplicity of infection; PBMC: peripheral blood mononuclear cells; PHA: phytohaemagglutinin; RSV: respiratory syncytial virus; TCR: T cell receptor; TLR4: toll-like receptor 4; Wisko: Wiskostatin.}

\section{Competing interests}

The authors declare that they have no competing interests.

\begin{abstract}
Author's contributions
$J$ carried out the design of the study, performed the immunoassays and the statistical analyses and drafted the manuscript. HE performed the immunoassays and helped draft the manuscript. RdG and MdJ participated in the design of the study and helped draft the manuscript. GF carried out the coordination and the design of the study, participated in the statistical analysis and drafted the manuscript. All authors read and approved the final manuscript.
\end{abstract}

\section{Acknowledgements}

We would like to thank Dr. M.E. Peeples, Ohio State University, for kindly providing us with a transgenic RSV strain expressing renilla-GFP.
Received: 19 October 2015 Accepted: 14 March 2016

Published online: 22 March 2016

\section{References}

1. Hall CB, Walsh EE, Long CE, Schnabel KC. Immunity to and frequency of reinfection with respiratory syncytial virus. J Infect Dis. 1991;163:693-8.

2. Midulla F, Huang YT, Gilbert IA, Cirino NM, McFadden Jr ER, Panuska JR. Respiratory syncytial virus infection of human cord and adult blood monocytes and alveolar macrophages. Am Rev Respir Dis. 1989;140:771-7.

3. Soukup JM, Becker S. Role of monocytes and eosinophils in human respiratory syncytial virus infection in vitro. Clin Immunol. 2003;107:178-85.

4. Schijf MA, Lukens MV, Kruijsen D, van Uden NO, Garssen J, Coenjaerts FE, Van't Land B, van Bleek GM. Respiratory syncytial virus induced type I IFN production by $\mathrm{pDC}$ is regulated by RSV-infected airway epithelial cells. RSVexposed monocytes and virus specific antibodies. PLOS ONE. 2013;8, e81695.

5. Takeuchi R, Tsutsumi H, Osaki M, Haseyama K, Mizue N, Chiba S. Respiratory syncytial virus infection of human alveolar epithelial cells enhances interferon regulatory factor 1 and interleukin-1beta-converting enzyme gene expression but does not cause apoptosis. J Virol. 1998;72:4498-502.

6. Thomas LH, Wickremasinghe MI, Sharland M, Friedland JS. Synergistic upregulation of interleukin-8 secretion from pulmonary epithelial cells by direct and monocyte-dependent effects of respiratory syncytial virus infection. J Virol. 2000;74:8425-33.

7. Gaona J, Santiago-Olivares C, Ortega E, Gomez B. Respiratory syncytial virus persistence in macrophages upregulates Fcgamma receptors expression. Viruses. 2014;6:624-39.

8. Goritzka M, Makris S, Kausar F, Durant LR, Pereira C, Kumagai Y, Culley FJ, Mack M, Akira S, Johansson C. Alveolar macrophage-derived type I interferons orchestrate innate immunity to RSV through recruitment of antiviral monocytes. J Exp Med. 2015;212:699-714.

9. Kurt-Jones EA, Popova L, Kwinn L, Haynes LM, Jones LP, Tripp RA, Walsh EE, Freeman MW, Golenbock DT, Anderson L, Finberg RW. Pattern recognition receptors TLR4 and CD14 mediate response to respiratory syncytial virus. Nat Immunol. 2000;1:398-401.

10. Haynes LM, Moore DD, Kurt-Jones EA, Finberg RW, Anderson LJ, Tripp RA. Involvement of toll-like receptor 4 in innate immunity to respiratory syncytial virus. J Virol. 2001;75:10730-7.

11. Bhoj VG, Sun Q, Bhoj EJ, Somers C, Chen X, Torres JP, Mejias A, Gomez AM, Jafri H, Ramilo O, Chen ZJ. MAVS and MyD88 are essential for innate immunity but not cytotoxic T lymphocyte response against respiratory syncytial virus. Proc Natl Acad Sci U S A. 2008;105:14046-51.

12. Humphries AC, Way M. The non-canonical roles of clathrin and actin in pathogen internalization, egress and spread. Nat Rev Microbiol. 2013;11: 551-60.

13. Grove J, Marsh M. The cell biology of receptor-mediated virus entry. J Cell Biol. 2011;195:1071-82

14. Edinger TO, Pohl MO, Stertz S. Entry of influenza a virus: host factors and antiviral targets. J Gen Virol. 2014;95:263-77.

15. Matsuda M, Suzuki R, Kataoka C, Watashi K, Aizaki H, Kato N, Matsuura Y, Suzuki T, Wakita T. Alternative endocytosis pathway for productive entry of hepatitis C virus. J Gen Virol. 2014.

16. Vazquez-Calvo A, Saiz JC, McCullough KC, Sobrino F, Martin-Acebes MA. Acid-dependent viral entry. Virus Res. 2012;167:125-37.

17. Kuhn DA, Vanhecke D, Michen B, Blank F, Gehr P, Petri-Fink A, RothenRutishauser B. Different endocytotic uptake mechanisms for nanoparticles in epithelial cells and macrophages. Beilstein J Nanotechnol. 2014;5:1625-36.

18. Ryckman BJ, Chase MC, Johnson DC. HCMV gH/gL/UL128-131 interferes with virus entry into epithelial cells: evidence for cell type-specific receptors. Proc Natl Acad Sci U S A. 2008:105:14118-23.

19. Krzyzaniak MA, Zumstein MT, Gerez JA, Picotti P, Helenius A. Host cell entry of respiratory syncytial virus involves macropinocytosis followed by proteolytic activation of the F protein. PLoS Pathog. 2013;9, e1003309.

20. Kolokoltsov AA, Deniger D, Fleming EH, Roberts Jr NJ, Karpilow JM, Davey RA. Small interfering RNA profiling reveals key role of clathrin-mediated endocytosis and early endosome formation for infection by respiratory syncytial virus. J Virol. 2007;81:7786-800.

21. Werling D, Hope JC, Chaplin P, Collins RA, Taylor G, Howard CJ. Involvement of caveolae in the uptake of respiratory syncytial virus antigen by dendritic cells. J Leukoc Biol. 1999;66:50-8. 
22. Gutierrez-Ortega A, Sanchez-Hernandez C, Gomez-Garcia B. Respiratory syncytial virus glycoproteins uptake occurs through clathrin-mediated endocytosis in a human epithelial cell line. Virol J. 2008;5:127.

23. Sainz Jr B, Mossel EC, Peters CJ, Garry RF. Interferon-beta and interferongamma synergistically inhibit the replication of severe acute respiratory syndrome-associated coronavirus (SARS-CoV). Virology. 2004;329:11-7.

24. Kruijsen D, Bakkers MJ, van Uden NO, Viveen MC, van der Sluis TC, Kimpen $J$, Leusen JH, Coenjaerts FE, van Bleek GM. Serum antibodies critically affect virus-specific CD4+/CD8+ T cell balance during respiratory syncytial virus infections. J Immunol. 2010;185:6489-98.

25. Thomas LH, Sharland M, Friedland JS. Steroids fail to down-regulate respiratory syncytial virus-induced IL-8 secretion in infants. Pediatr Res. 2002; 52:368-72.

26. Heidema J, de Bree GJ, De Graaff PM, van Maren WW, Hoogerhout P, Out TA, Kimpen JL, van Bleek GM. Human CD8(+) T cell responses against five newly identified respiratory syncytial virus-derived epitopes. J Gen Virol. 2004;85:2365-74.

27. Vissers M, Habets MN, Ahout IM, Jans J, de Jonge MI, Diavatopoulos DA, Ferwerda G. An in vitro model to study immune responses of human peripheral blood mononuclear cells to human respiratory syncytial virus infection. J Vis Exp. 2013;82:e50766.

28. Dietzel E, Kolesnikova L, Maisner A. Actin filaments disruption and stabilization affect measles virus maturation by different mechanisms. Virol J. 2013;10:249

29. Wang S, Huang X, Huang Y, Hao X, Xu H, Cai M, Wang H, Qin Q. Entry of a novel marine DNA virus, Singapore grouper iridovirus, into host cells occurs via clathrin-mediated endocytosis and macropinocytosis in a pH-dependent manner. J Virol. 2014;88:13047-63.

30. Cafruny WA, Duman RG, Wong GH, Said S, Ward-Demo P, Rowland RR, Nelson EA. Porcine reproductive and respiratory syndrome virus (PRRSV) infection spreads by cell-to-cell transfer in cultured MARC-145 cells, is dependent on an intact cytoskeleton, and is suppressed by drug-targeting of cell permissiveness to virus infection. Virol J. 2006;3:90.

31. Simms PE, Ellis TM. Utility of flow cytometric detection of CD69 expression as a rapid method for determining poly- and oligoclonal lymphocyte activation. Clin Diagn Lab Immunol. 1996;3:301-4.

32. Netea MG, Stuyt RJ, Kim SH, Van der Meer JW, Kullberg BJ, Dinarello CA. The role of endogenous interleukin (IL)-18, IL-12, IL-1 beta, and tumor necrosis factor-alpha in the production of interferon-gamma induced by Candida albicans in human whole-blood cultures. J Infect Dis. 2002;185:963-70.

33. Pernet $\mathrm{O}$, Pohl C, Ainouze M, Kweder $H$, Buckland R. Nipah virus entry can occur by macropinocytosis. Virology. 2009;395:298-311.

34. Hernanz-Falcon $\mathrm{P}$, Joffre $\mathrm{O}$, Williams $\mathrm{DL}$, Reis e Sousa C. Internalization of Dectin-1 terminates induction of inflammatory responses. Eur J Immunol. 2009:39:507-13.

35. Mueller A, Strange PG. Mechanisms of internalization and recycling of the chemokine receptor, CCR5. Eur J Biochem. 2004;271:243-52.

36. Tayyari F, Marchant D, Moraes TJ, Duan W, Mastrangelo P, Hegele RG. Identification of nucleolin as a cellular receptor for human respiratory syncytial virus. Nat Med. 2011;17:1132-5.

37. Kagan JC, Su T, Horng T, Chow A, Akira S, Medzhitov R. TRAM couples endocytosis of Toll-like receptor 4 to the induction of interferon-beta. Nat Immunol. 2008;9:361-8.

38. Poussin C, Foti M, Carpentier JL, Pugin J. CD14-dependent endotoxin internalization via a macropinocytic pathway. J Biol Chem. 1998;273:20285-91.

39. Hovanessian AG, Puvion-Dutilleul F, Nisole S, Svab J, Perret E, Deng JS, Krust $B$. The cell-surface-expressed nucleolin is associated with the actin cytoskeleton. Exp Cell Res. 2000;261:312-28.

40. Kallewaard NL, Bowen AL, Crowe Jr JE. Cooperativity of actin and microtubule elements during replication of respiratory syncytial virus. Virology. 2005:331:73-81.

41. Ravi LI, Liang L, Wong PS, Brown G, Tan BH, Sugrue RJ. Increased hydroxymethylglutaryl coenzyme A reductase activity during respiratory syncytial virus infection mediates actin dependent inter-cellular virus transmission. Antiviral Res. 2013;100:259-68.

42. Gower TL, Pastey MK, Peeples ME, Collins PL, McCurdy LH, Hart TK, Guth A Johnson TR, Graham BS. RhoA signaling is required for respiratory syncytial virus-induced syncytium formation and filamentous virion morphology. J Virol. 2005;79:5326-36.

43. Shaikh FY, Utley TJ, Craven RE, Rogers MC, Lapierre LA, Goldenring JR, Crowe JE Jr. Respiratory syncytial virus assembles into structured filamentous virion particles independently of host cytoskeleton and related proteins. PLoS ONE. 2012;7, e40826.

44. Franke-Ullmann G, Pfortner C, Walter P, Steinmuller C, Lohmann-Matthes ML, Kobzik L, Freihorst J. Alteration of pulmonary macrophage function by respiratory syncytial virus infection in vitro. J Immunol. 1995;154:268-80.

45. Marr N, Turvey SE. Role of human TLR4 in respiratory syncytial virus-induced NFkappaB activation, viral entry and replication. Innate Immun. 2012;18:856-65.

46. Calabia-Linares C, Robles-Valero J, de la Fuente H, Perez-Martinez M, MartinCofreces N, Alfonso-Perez M, Gutierrez-Vazquez C, Mittelbrunn M, Ibiza S, Urbano-Olmos FR, et al. Endosomal clathrin drives actin accumulation at the immunological synapse. J Cell Sci. 2011;124:820-30.

47. de Bree GJ, Heidema J, van Leeuwen EM, van Bleek GM, Jonkers RE, Jansen HM, van Lier RA, Out TA. Respiratory syncytial virus-specific CD8+ memory T cell responses in elderly persons. J Infect Dis. 2005;191:1710-8.

48. Heidema J, Rossen JW, Lukens MV, Ketel MS, Scheltens E, Kranendonk ME, van Maren WW, van Loon AM, Otten HG, Kimpen JL, van Bleek GM. Dynamics of human respiratory virus-specific CD8+ T cell responses in blood and airways during episodes of common cold. J Immunol. 2008;181:5551-9.

49. McCormick PJ, Martina JA, Bonifacino JS. Involvement of clathrin and AP-2 in the trafficking of MHC class II molecules to antigen-processing compartments. Proc Natl Acad Sci U S A. 2005;102:7910-5.

50. Vissers M, Schreurs I, Jans J, Heldens J, de Groot R, de Jonge MI, Ferwerda G. Antibodies enhance CXCL10 production during RSV infection of infant and adult immune cells. Cytokine. 2015;76:458-64.

\section{Submit your next manuscript to BioMed Central and we will help you at every step:}

- We accept pre-submission inquiries

- Our selector tool helps you to find the most relevant journal

- We provide round the clock customer support

- Convenient online submission

- Thorough peer review

- Inclusion in PubMed and all major indexing services

- Maximum visibility for your research

Submit your manuscript at www.biomedcentral.com/submit
C Biomed Central 